\title{
Gluten specific, HLA-DQ restricted T cells from coeliac mucosa produce cytokines with Th1 or Th0 profile dominated by interferon $\gamma$
}

\author{
E M Nilsen, K E A Lundin, P Krajči, H Scott, L M Sollid, P Brandtzaeg
}

\begin{abstract}
Coeliac disease is precipitated in susceptible subjects by ingestion of wheat gluten or gluten related prolamins from some other cereals. The disease is strongly associated with certain HLA-DQ heterodimers, for example, DQ2 $(D Q \alpha 1 * 0501, \beta 1 * 0201)$ in most patients and apparently DQ8 (DQ $\alpha 11^{\star 0301,}$ $\beta 1{ }^{\star 0302)}$ in a small subset. Gluten specific $T$ cell clones (TCC) from coeliac intestinal lesions were recently established and found to be mainly restricted by HLA-DQ2 or HLA-DQ8. Antigen induced production of cytokines was studied in 15 TCC from three patients, 10 being DQ2 and five DQ8 restricted. Cell culture supernatants were prepared by stimulation with gluten peptides in the presence of $\mathrm{DQ2}^{+}$or $\mathrm{DQ8}^{+}$Epstein-Barr virus transformed $B$ cells as antigen presenting cells (APC). Supernatants were analysed for cytokines by bioassays, ELISA, and CELISA. Cellular cytokine mRNA was analysed semi-quantitatively by slot blotting and polymerase chain reaction (PCR). All TCC were found to secrete interferon (IFN) $\gamma$, often at high concentrations $(>2000 \mathrm{U} / \mathrm{ml})$; some secreted in addition interleukin (IL) 4, IL 5, IL 6, IL 10, tumour necrosis factor (TNF), and transforming growth factor (TGF) $\beta$. The last TCC thus displayed a Th0-like cytokine pattern. However, other TCC produced IFN $\gamma$ and TNF but no IL 4, or IL 5, compatible with a Th1like pattern. In conclusion, most DQ8 restricted TCC seemed to fit with a Th0 profile whereas the DQ2 restricted TCC secreted cytokines more compatible with a Th1 pattern. The TCC supernatants induced upregulation of HLA-DR and secretory component (poly-Ig receptor) in the colonic adenocarcinoma cell line HT-29.E10, most probably reflecting mainly the high IFN $\gamma$ concentrations. This cytokine, particularly in combination with TNF $\alpha$, might be involved in several pathological features of the coeliac lesion. The characterised cytokine profiles thus support the notion that mucosal $T$ cells activated in situ by gluten in a DQ restricted fashion play a central part in the pathogenesis of coeliac disease. (Gut 1995; 37: 766-776)
\end{abstract}

Keywords: coeliac disease, $\mathrm{T}$ cell subset, cytokines, mucosal immunity, HLA-DQ restriction.
Coeliac disease or gluten sensitive enteropathy is a proximal small intestinal disorder characterised by various degrees of crypt cell hyperplasia and villous atrophy. ${ }^{12}$ The result is malabsorption and often diarrhoea. The disease is precipitated in susceptible subjects by ingestion of cereal proteins, particularly the gliadins of wheat gluten as well as similar prolamins present in rye and to a lesser extent in barley. Withdrawal of these nutrients from the diet usually results in normalisation of the intestinal morphology.

Virtually all northern European coeliac patients carry the HLA-DR3, -DQ2 haplotype or, alternatively, are HLA-DR5, -DQ7/HLADR7, -DQ2 heterozygous; they therefore share the $\mathrm{DQ}\left(\alpha 1^{\star} 0501, \beta 1^{\star} 0201\right)$ heterodimer encoded either in cis or in trans. ${ }^{34}$ A population dependent varying subset of clinically typical coeliac patients lack this heterodimer, however, but seem, instead, to carry DQ8 encoded by DR4 positive haplotypes. ${ }^{5} 6$

The biological link between the strong HLA association in coeliac disease and the immunopathology of the mucosal lesion has not been elucidated. Gluten challenge of treated patients (that is, previously taking a gluten free diet) induces systemic as well as mucosal immune activation. ${ }^{7-12}$ Hyperactivation of mucosal $\mathrm{T}$ cells seems to be an important feature of the disease. ${ }^{11}$ It has been speculated that local generation of various cytokines may contribute to increased permeability and damage of the epithelium, ${ }^{13} 14$ upregulation of epithelial HLA class II and secretory component or polymeric immunoglobulin receptor expression, ${ }^{15-18}$ as well as expansion and terminal differentiation of mucosal B cells. ${ }^{19}$ All these phenomena are seen in the active coeliac lesion.

Gluten responsive $\mathrm{T}$ cell clones (TCC) were recently established ${ }^{20-22}$ from coeliac mucosa challenged with gluten peptides in vitro. ${ }^{12}$ Such TCC were obtained from two patients with the major disease susceptibility haplotype HLA-DR3, -DQ2 and from one with the HLA-DR4, -DQ8 haplotype. All clones were $\mathrm{T}$ cell receptor $(\mathrm{TcR}) \alpha / \beta^{+}, \mathrm{CD}^{+}, \mathrm{CD}^{+}$, $\mathrm{CD}^{+}, \mathrm{CD}^{-}$, and the predominant $\mathrm{T}$ cell restriction was exerted by the disease susceptibility molecules DQ $\left(\alpha 1^{\star} 0501, \beta 1^{\star} 0201\right)$ (a variant of $\mathrm{DQ} 2)$ or $\mathrm{DQ}\left(\alpha 1^{\star} 0301, \beta 1^{\star} 0302\right)$ (DQ8) in the respective cases. ${ }^{20-22}$ In this study a number of cytokines produced by such gluten responsive mucosal TCC were characterised by biological and immunological assays. Cellular cytokine mRNA was analysed by slot blotting and, for low expression values, 
TABLE I Summary of tests performed for each human cytokine

\begin{tabular}{lllll}
\hline Cytokine & Bioassay & Immunoassay & Slot blot & $R T-P C R^{\star}$ \\
\hline IFN $\gamma$ & Yes & No & Yes & Yes \\
TNF $\alpha$ & Yes & Yes & Yes & Yes \\
TGF $\beta$ & Yes & No & No & Yes \\
IL 2 & Yes & Yes & No & Yes \\
IL 4 & No & Yes & Yes & Yes \\
IL 5 & Yes & No & No & Yes \\
IL 6 & Yes & No & No & Yes \\
IL 10 & No & Yes & No & Yes \\
\hline
\end{tabular}

${ }^{\star}$ Reverse transcriptase-polymerase chain reaction.

by the more sensitive polymerase chain reaction (PCR). Both Th1- and Th0-like profiles were revealed but the major product was interferon (IFN) $\gamma$, which might explain several immunopathological features of the active coeliac lesion.

\section{Methods}

\section{$T$ cell clones}

Gluten reactive mucosal TCC were prepared from three treated coeliac patients as detailed elsewhere. ${ }^{20-22}$ Patient no 1 was typed as HLA-DR3, -DQ1,2 and patient no 2 as HLADR1,3, -DQ1,2, whereas patient no 3 was typed as HLA-DR4, -DQ7,8. Briefly, jejunal biopsy specimens were incubated with a peptic-tryptic digest of gluten for 18 hours. ${ }^{12}$ After collagenase digestion activated interleukin (IL) 2 receptor positive $T$ cells were selected by immunomagnetic beads armed with antiCD25. The $T$ cells were then expanded and cloned ( 0.5 cells/well) in RPMI 1640 medium (Gibco, Paisley, Scotland) with $15 \%$ pooled inactivated human serum, penicillin (100 $\mathrm{U} / \mathrm{ml}$ ), streptomycin $(100 \mu \mathrm{g} / \mathrm{ml})$, recombinant (r) human (h) IL2 (5 Uml) and phytohaemagglutinin (l $\mu \mathrm{g} / \mathrm{ml}$, Wellcome, Dartford, UK). The TCC recognised gliadins from a range of wheat varieties, but not pepsintrypsin. ${ }^{20} 21$ When tested against one purified $\alpha$ gliadin and two purified $\gamma$ gliadins, evidence for a pronounced heterogeneity with respect to epitopes recognised was obtained (Lundin et al, unpublished data), but the epitopes have not yet been defined at the peptide level. The cytokine profiles of 15 TCC were analysed, including two sister clones carrying the same $\mathrm{TcR} \alpha / \beta$ genes. One TCC reactive with Mycobacterium tuberculosis was included as a control; this clone was established from the peripheral blood of coeliac patient no 4 typed as HLA-DR3, -DQ2 (Lundin et al, unpublished data). Table I summarises the methods used to detect the various cytokines.

\section{Preparation of TCC supernatants and proliferative assays}

To analyse the cytokine profiles of TCC, the cells were stimulated with the peptic-tryptic gluten digest $(1-2 \mathrm{~g} / \mathrm{l})$ in the presence of antigen presenting cells (APC) expressing the relevant HLA class II restriction element - that is, DQ2 for patients no 1 and no 2, and DQ8 for patient no 3 . The $T$ cells $\left(5 \times 10^{5}\right)$ were incubated with the gluten antigens and
Epstein-Barr virus transformed B cells $\left(1 \times 10^{6}\right.$, irradiated at $10 \mathrm{~Gy}$ ) used as APC in $1.5-2 \mathrm{ml}$ medium (RPMI 1640 containing 15\% inactivated human serum and antibiotics). Supernatants from parallel cultures without gluten antigens served as negative controls. In preliminary experiments supernatants were collected after $12,24,36$, and 48 hours of stimulation, but 48 hours was used subsequently as this was found to be the most optimal time point. The samples were cleared by centrifugation and stored as aliquots at $-70^{\circ} \mathrm{C}$.

Proliferative assays of TCC were performed in $0.2 \mathrm{ml}$ medium (RPMI 1640 with $15 \%$ inactivated human serum and antibiotics) with $2 \times 10^{4} \mathrm{~T}$ cells stimulated in triplicate with $5 \times 10^{4}$ irradiated APC in the presence or absence of gluten. ${ }^{20}$ The peptic-tryptic gluten digest was used at 1-2 g/l. The cells were pulsed with ${ }^{3} \mathrm{H}$-thymidine after about 48 hours and harvested 18 hours thereafter.

\section{Standards and probes for cytokines}

The cytokines rh IFN $\gamma$, rh tumour necrosis factor (TNF) $\alpha$, rh transforming growth factor (TGF) $\beta$, rhIL 5, and rhIL 6 were obtained from Genzyme Corporation (Cambridge, MA), and rhIL-2 from Amersham International (Amersham, Buckinghamshire, $\mathrm{UK})$. Activity units (U) were based on information given by the manufacturers. Supernatant from transformed X63Ag8-653 myeloma cells ${ }^{23}$ containing murine (m) IL 5 was kindly provided by B Bogen (IGRI, Rikshospitalet, Oslo, Norway). Single stranded antisense DNA probes for hIL 2 (BPR 13), hIL 4 (BPR 22), hIL 5 (BPR 27), hIL 6 (BPR 32), hTNF $\alpha$ (BPR 49), and hIFN $\gamma$ (BPR 216) were purchased from $R \& D$ Systems Europe Ltd (Abingdon, UK). All probes recognised certain exons of the relevant gene, and the probe mixture was equimolar with regard to the region specific probes. The primer sets for hIFN $\gamma$, hTNF $\alpha$, and hIL 2 were commercially synthesised (R\&D Systems Europe Ltd), whereas the primer sets for $h \beta$ actin, hTGF $\beta$, hIL 4, hIL 5, hIL 6 , and hIL 10 were generous gifts from I Moro (Department of Pathology, Nihon University School of Dentistry, Tokyo, Japan). All primer sequences were derived from separate exons of the gene sequences, thus spanning intron(s); amplification products of genomic DNA could therefore be distinguished from products of reverse transcribed mRNA. Table II lists the primer set sequences.

\section{Cell lines for bioassays}

The human colonic adenocarcinoma cell line HT-29.E10 was provided by K E Mostov (Department of Anatomy, Biochemistry, Biophysics and Cardiovascular Research Institute, University of California, San Francisco, CA), the mouse fibrosarcoma cell line WEHI 164 clone 13, the mink lung cell line CCL-64 as well as the mouse hybridoma cell line B9 by T Espevik (Institute of Cancer 
TABLE II Specifications of the primer sets used in analyses of $m R N A$ expression for human cytokines

\begin{tabular}{|c|c|c|c|}
\hline Cytokine & Primer set & $\begin{array}{l}\text { Annealing } \\
\text { temperature }\end{array}$ & $\begin{array}{l}\text { PCR product } \\
\text { size }(b p)\end{array}$ \\
\hline IFN $\gamma$ & $\begin{array}{l}\text { 5'-AATGCAGGTCATTCAGATG-3' } \\
\text { 5'-TTGGACATTCAAGTCAGTT-3' }\end{array}$ & $55^{\circ} \mathrm{C}$ & 270 \\
\hline TNF $\alpha$ & $\begin{array}{l}\text { 5'-CAGAGGGAAGAGTTCCCCAG-3' } \\
\text { 5'-CCTTGGTCTGGTAGGAGACG-3' }\end{array}$ & $60^{\circ} \mathrm{C}$ & 325 \\
\hline TGF $\beta$ & $\begin{array}{l}\text { 5'-CAGAAATACAGCAACAATTCCTGG-3' } \\
\text { 5'-TTGCAGTGTGTTATCCGTGCTGTC-3' }\end{array}$ & $60^{\circ} \mathrm{C}$ & 187 \\
\hline IL 2 & $\begin{array}{l}\text { 5'-GAATGGAATTAATAATTACAAGAATCCC-3' } \\
\text { 5'-TGTTTCAGATCCATTTAGTTCCAG-3' }\end{array}$ & $60^{\circ} \mathrm{C}$ & 222 \\
\hline IL 4 & $\begin{array}{l}\text { 5'-CACAAGTGCGATATCACCTT-3' } \\
\text { 5'-GCTCGAACACTTTGAATATT-3' }\end{array}$ & $60^{\circ} \mathrm{C}$ & 386 \\
\hline IL 5 & $\begin{array}{l}\text { 5'-ATGAGGATGCTTCTGCATTTG-3' } \\
\text { 5'-TTCAGTGCACAGTTGGTG-3' }\end{array}$ & $55^{\circ} \mathrm{C}$ & 193 \\
\hline IL 6 & $\begin{array}{l}\text { 5'-ATGAACTCCTTCTCCACAAGCGC-3' } \\
\text { 5'-GAAGAGCCCTCAGGCTGGACTG-3' }\end{array}$ & $60^{\circ} \mathrm{C}$ & 611 \\
\hline IL 10 & $\begin{array}{l}\text { 5'-CTTTCAAATGAAGGATCAGC-3' } \\
\text { 5'-ATGTCAAACTCACTCATGGC-3' }^{\prime}\end{array}$ & $55^{\circ} \mathrm{C}$ & 326 \\
\hline$\beta$ Actin & $\begin{array}{l}\text { 5'-TTCCAGCCTTCCTTCCTGG-3' } \\
\text { 5'-TTGCGCTCAGGAGGAGCAA-3' }\end{array}$ & $55^{\circ} \mathrm{C}$ & 222 \\
\hline
\end{tabular}

Research, Trondheim, Norway), the murine $T$ cell line HT-2 by T Lea (IGRI, Rikshospitalet, Oslo, Norway), and the mouse $B$ cell line LYH7.B13 by $R$ Palacios (Department of Immunology, Houston, TX). The HT-2 cells were cultured in 24 well plates (Costar Corp, Cambridge, MA) at $37^{\circ} \mathrm{C}$ with humidified $5 \%$ $\mathrm{CO}_{2}$, the other cells in $75 \mathrm{~cm}^{2}$ flasks (Costar). The HT-29.E10, WEHI 164 clone 13, and CCL-64 cells were grown in RPMI 1640 medium supplemented with L-glutamine, penicillin $(100 \mathrm{U} / \mathrm{ml})$, streptomycin (100 $\mu \mathrm{g} / \mathrm{ml}$ ), and $10 \%$ fetal calf serum. The other cell lines were kept in the same medium supplemented with L-glutamine, gentamicin, $5 \times 10^{-5} \mathrm{M} \beta$-mercaptoethanol, non-essential amino acids, $1 \mathrm{mM}$ sodiumpyruvate, and $10 \%$ fetal calf serum with one of the following growth factors added: rhIL 2 (for HT-2); supernatant from lipopolysaccharide stimulated human peripheral blood mononuclear cells (PBMC) (for B9); or supernatant from X63Ag8-653 cells containing $\mathrm{mIL} 5$ (for LYH7.B13).

\section{Bioassays for cytokines}

IL 2, IL 5, and IL 6 activities were measured in proliferative bioassays with the murine cell line HT-2, LYH7.B13 or B9, respectively. These assays and their specificities have been detailed elsewhere. ${ }^{24-26}$ Standard curves were prepared with rhIL 2 , rhIL 5, and rhIL 6. TNF $\alpha$ and TNF $\beta$ activities were collectively measured in a cytotoxic bioassay with the murine cell line WEHI 164 clone $13^{27}$; rhTNF $\alpha$ was used as a standard and lysis was quantified by the colorimetric 3-(4,5-dimethylthiazol-2-yl)-2,5difenyltetrazolium bromide (MTT) method. ${ }^{28}$ TGF $\beta$ activity was measured in a cytotoxic bioassay with the mink lung cell line CCL-64, following acid activation ${ }^{29}$; rhTGF $\beta$ was used as a standard. Table III summarises the specificities of the cell lines, their culture conditions, and references.

\section{Cell ELISA for epithelial secretory component and} $H L A-D R$

Total cellular secretory component and HLA-DR expression was determined by a semi-quantitative cell ELISA (CELISA) as detailed elsewhere. ${ }^{30}$ Briefly, a single cell suspension of HT-29.E10 was seeded out in triplicates in a 96 well plate (Costar), $5 \times 10^{4}$ cells/well. After 30 hours at $37^{\circ} \mathrm{C}$ the medium was removed and TCC supernatants (diluted $1 / 20$ in $150 \mu 1$ medium) were added to the wells and incubated for 48 hours at $37^{\circ} \mathrm{C}$. The wells were washed with isotonic phosphate buffered saline, $\mathrm{pH} 7 \cdot 5$, fixed in $70 \%$ ethanol for five minutes at room temperature, and air dried for at least one hour. The following antibody reagents, diluted in phosphate buffered saline containing $2 \%$ (w/v) bovine serum albumin (Behringwerke, Marburg, Germany) were used: primary monoclonal mouse antihuman secretory component (ascitic fluid, diluted 1/600; gift from J Bartèk, Institute of Clinical and Experimental Cancer Research, Brno, Czech Republic); primary monoclonal mouse antihuman HLADR (clone L243, purified IgG, diluted 1/1600; Becton Dickinson, Mountain View, CA); secondary rabbit antimouse IgG (purified IgG, diluted 1/800; Dakopatts, Glostrup, Denmark); and finally peroxidase conjugated antirabbit IgG (diluted 1/3000; Dakopatts). The background was calculated from parallel wells in which the primary reagent had been replaced by phosphate buffered saline containing $2 \%(\mathrm{w} / \mathrm{v})$ bovine serum albumin.

TABLE III Characteristics of cell lines used in bioassays for the detection of human cytokines

\begin{tabular}{|c|c|c|c|c|c|}
\hline Cell line & Origin & Assay & Specificity & Additions to ordinary culture conditions & References \\
\hline HT-29 E10 & $\begin{array}{l}\text { Human colonic } \\
\text { adenocarcinoma } \\
\text { cell line }\end{array}$ & Cell ELISA & IFN $\gamma$ & None & Kvale, $1992^{30}$ \\
\hline $\begin{array}{l}\text { WEHI } 164 \\
\text { clone } 13\end{array}$ & $\begin{array}{l}\text { Murine } \\
\text { fibrosarcoma } \\
\text { cell line }\end{array}$ & Cytotoxicity & TNF $\alpha$ or $\beta$ & None & $\begin{array}{l}\text { Espevik and Nissen- } \\
\text { Meyer, } 1986^{27}\end{array}$ \\
\hline CCL-64 & $\begin{array}{l}\text { Mink lung } \\
\text { epithelial cells }\end{array}$ & Cytotoxicity & TGF $\beta$ & None & Danielpoor, $1989^{29}$ \\
\hline HT-2 & $\begin{array}{l}\text { Murine T helper } \\
\text { cell line }\end{array}$ & Proliferation & IL 2 & $\begin{array}{l}5 \times 10^{5} \mathrm{M} \beta \text {-mercaptoethanol non- } \\
\text { essential amino acids } 1 \mathrm{mM} \text { sodium } \\
\text { pyruvate } 5 \mathrm{U} / \mathrm{ml} \text { rhIL } 2\end{array}$ & Watson, $1979^{24}$ \\
\hline LYH7.B13 & Mouse B cell line & Proliferation & IL 5 & $\begin{array}{l}5 \times 10^{5} \mathrm{M} \beta \text {-mercaptoethanol non- } \\
\text { essential amino acids } 1 \mathrm{mM} \text { sodium } \\
\text { pyruvate } 5 \mathrm{U} / \mathrm{ml} \text { rhIL } 2 \text { supernatant } \\
\text { from } \mathrm{X} 63 \mathrm{Ag} 8-653 \text { cells }\end{array}$ & Fattah, $1990^{26}$ \\
\hline $\begin{array}{l}\text { B9 (clone B- } \\
\text { 92504) }\end{array}$ & $\begin{array}{l}\text { Murine hybridoma } \\
\text { cell line }\end{array}$ & Proliferation & IL 6 & $\begin{array}{l}5 \times 10^{5} \mathrm{M} \beta \text {-mercaptoethanol non- } \\
\text { essential amino acids } 1 \mathrm{mM} \text { sodium } \\
\text { pyruvate } 5 \mathrm{U} / \mathrm{ml} \text { rhIL } 2 \text { supernatant } \\
\text { from lipopolysaccharide stimulated } \\
\text { human PBMC }\end{array}$ & Helle, $1988^{25}$ \\
\hline
\end{tabular}




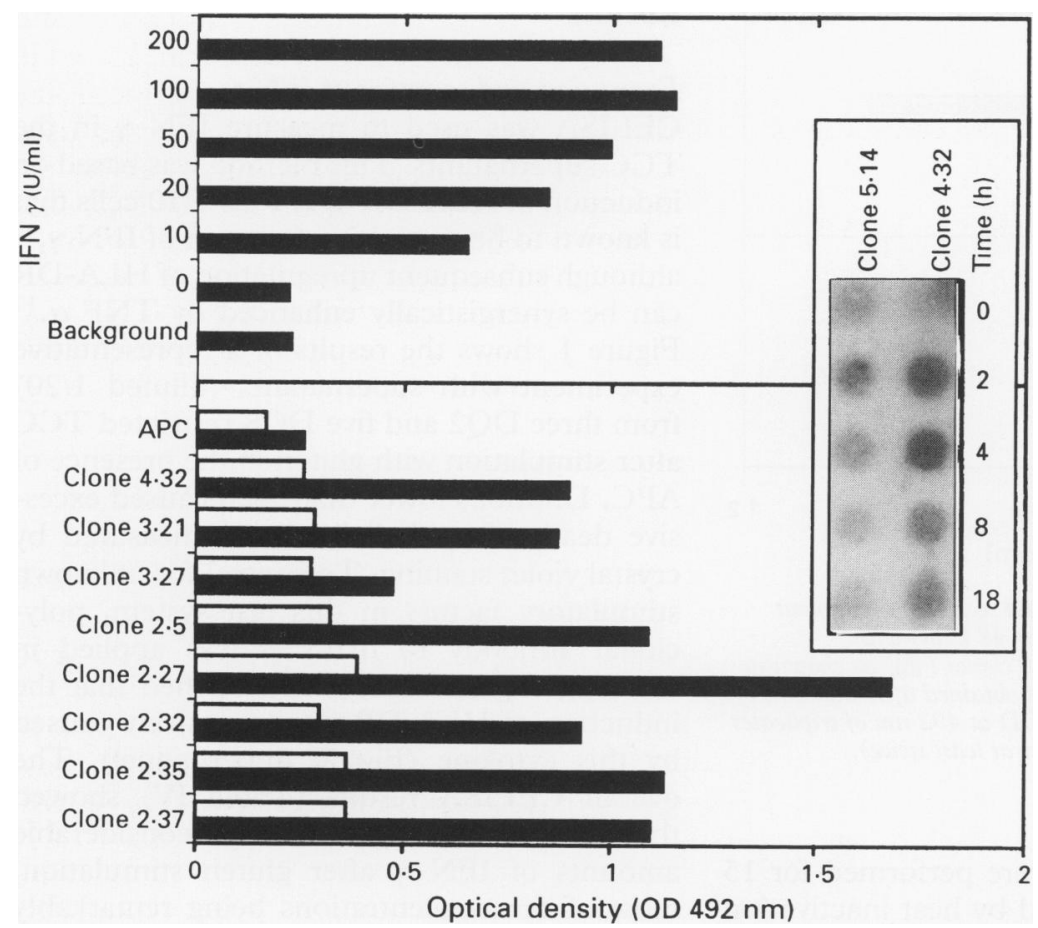

Figure 1: CELISA measurements of HLA-DR expression by HT-29.E10 cells after stimulation for 48 hours with supernatants (diluted 1/20) from various gluten stimulated $T$ cell clones ( $)$ as shown (lower panel) in relation to APC alone, clonal control without gluten ( $\square$ ), and reference values obtained with 0-200 U/ml of rhIFN $\gamma(\square)$ (upper panel). Results presented as mean OD at $492 \mathrm{~nm}$ of triplicates tested in the same experiment (repeated in a reproducible manner at least twice). Insert shows autoradiogram of slot blot hybridisation results with antisense DNA probe for IFN $\gamma$ mRNA from two gluten stimulated (2-18 hours) T cell clones as shown, compared with unstimulated control (0 hours).

Inhibition of secretory component and $H L A-D R$ expression by antibody to IFN $\gamma$

Polyclonal rabbit antihuman IFN $\gamma$ (purified Ig, $16.7 \mathrm{~g} / \mathrm{l}$; gift from P Meide, TNO, Rijswijk, the Netherlands) was used to evaluate the inductive role of IFN $\gamma$ in TCC supernatants with regard to HLA-DR and secretory component expression measured by CELISA. The antibody ( $20 \mu \mathrm{l}$; diluted $1 / 500)$ was added to the TCC supernatant $(150 \mu \mathrm{l}$, final dilution $1 / 20$ ) at the assay start.

Immunoassays for cytokines

Commercial ELISA kits were used according to the manufacturers' recommendations for immunological quantification of hIL 2 and hIL 4 (Amersham) as well as h TNF $\alpha$ and hIL 10 (Medgenix Diagnostics, Brussels, Belgium).

TCC stimulation for $m R N A$ analysis

Total RNA from six TCC (clones $4 \cdot 32,5 \cdot 14$, $4 \cdot 81,3 \cdot 25,2 \cdot 27$, and $2 \cdot 37$ ) was isolated by the guanidium isothiocyanate method ${ }^{31}$ and quantified by spectrophotometry. RNA was extracted from $5 \times 10^{6} \mathrm{~T}$ cells after incubation with $5 \times 10^{6} \mathrm{APC}$ in the presence of gluten for $0,2,4,8$, or 18 hours (clones 4.32 and $5 \cdot 14$ ), and from $2.5 \times 10^{6} \mathrm{~T}$ cells after incubation with $2.5 \times 10^{6} \mathrm{APC}$ in the presence of gluten for 0 , 4 , or 8 hours (clones $4 \cdot 81,3 \cdot 25,2 \cdot 27$, and $2 \cdot 37)$.

Cytokine $m R N A$ analysis by slot blotting Nylon filters (Schleicher \& Schuell, Dassel,
Germany) were inserted in a slot blot apparatus (SRC 96 Minifold II; Schleicher \& Schuell) and presoaked by washing twice with $15 \times$ standard saline citrate. Samples of total RNA $(6 \mu \mathrm{g})$ were denatured by heating for 15 minutes at $65^{\circ} \mathrm{C}$ in $6 \times$ standard saline citrate with $7 \cdot 8 \%(\mathrm{v} / \mathrm{v})$ formaldehyde, and were next applied in $200 \mu \mathrm{l} 15 \times$ standard saline citrate onto filters, which thereafter were washed twice in $500 \mu l 15 \times$ standard saline citrate. Aspiration was continued for two minutes before the apparatus was disassembled and the filters were ultraviolet cross linked for two minutes and baked at $80^{\circ} \mathrm{C}$ for one hour. Single stranded antisense DNA probes for the various cytokines were labelled with $\left[\alpha^{32} \mathrm{P}\right]-$ ddATP at the $3^{\prime}$ end using terminal deoxynucleotidyl transferase (Amersham). Hybridisation with the $\left[\alpha^{32} \mathrm{P}\right]$-ddATP-labelled oligonucleotide probes $\left(1 \times 10^{6} \mathrm{cpm} / \mathrm{ml}\right)$ was performed overnight in $2 \times$ Denhardt's solution, $1 \times$ saline, sodium phosphate, and EDTA (SSPE), $1 \%$ (w/v) defatted dry milk, 10\% (w/v) dextran sulphate, 2\% (w/v) sodium dodecyl sulphate, and $200 \mu \mathrm{g} / \mathrm{ml}$ sheared single stranded salmon sperm DNA followed by washing into a final stringency of $0 \cdot 1 \times \mathrm{SSPE} / 0 \cdot 5 \%$ (w/v) SDS. Hybridisation and washing temperatures were performed $5^{\circ} \mathrm{C}$ below the calculated melting point based on the length of GC content for the respective probes. ${ }^{32}$ Autoradiography was performed with Hyperfilm-MP (Amersham) and intensifying screens (Eastman Kodak, Rochester, NY) for three to five days at $-70^{\circ} \mathrm{C}$.

Quality control of $m R N A$ by northern blotting Samples of total RNA $(20 \mu \mathrm{g})$ were denatured in $50 \%(\mathrm{v} / \mathrm{v})$ formamide, $6 \%(\mathrm{v} / \mathrm{v})$ formaldehyde, $2.4 \mathrm{mM}$ HEPES, $0.6 \mathrm{mM}$ sodium acetate, and $0.12 \mathrm{mM}$ EDTA at $50^{\circ} \mathrm{C}$ for 15 minutes; they were then subjected to electrophoresis in an agarose gel containing $6.7 \%$ (v/v) formaldehyde and $20 \mathrm{mM}$ sodium phosphate buffer ( $\mathrm{pH} 6 \cdot 5$ ), equal loading in each lane being verified by ethidium bromide staining. The agarose gel showed intractness of RNA for the two TCC tested in slot blot analysis (data not shown).

Polymerase chain reaction (PCR) for cytokine $m R N A$

For semi-quantitative analysis of cytokine mRNA performed with four TCC (clones $4 \cdot 81,3 \cdot 25,2 \cdot 27$, and $2 \cdot 37$ ), total RNA was extracted (see above), subjected to reverse transcription, and amplified by cytokine specific primers according to a standard protocol (Perkin Elmer Corporation, Norwalk, Conn). Total cellular RNA (100 ng) was reverse transcribed in a $20 \mu \mathrm{l}$ reaction mixture containing $5 \mathrm{mM} \mathrm{MgCl}, 1 \times$ PCR buffer (100 $\mathrm{mM}$ TRIS-HCl, pH 8.3; $500 \mathrm{mM} \mathrm{KCl}), 1$ $\mathrm{mM}$ dNTP, $20 \mathrm{U}$ RNAsin (Promega Corporation, Madison, WI), $20 \mathrm{pmol}$ oligo $(\mathrm{dT})_{16}$ primer, and $50 \mathrm{U}$ reverse transcriptase (Perkin Elmer). The reverse 


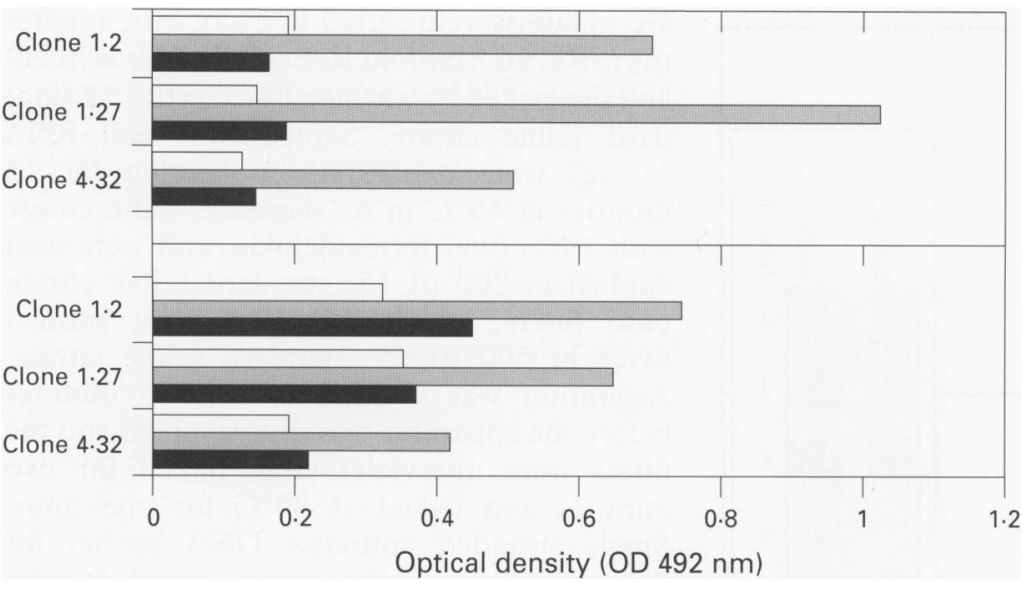

Figure 2: CELISA measurements of HLA-DR (upper panel) and secretory component (lower panel) expression by HT-29.E10 cells after stimulation for 48 hours with supernatants (diluted 1/20) from various gluten stimulated $T$ cell clones (圆) as shown in relation to clonal control without gluten ( $\square$ ) and parallel results obtained after addition of polyclonal antibody to IFN $\gamma(\square)$. Values presented as mean OD at $492 \mathrm{~nm}$ of triplicates tested in the same experiment (repeated in a reproducible manner at least twice).

transcription reactions were performed for 15 minutes at $42^{\circ} \mathrm{C}$ followed by heat inactivation at $99^{\circ} \mathrm{C}$ for 10 minutes. Volumes of $1 \mu l(\beta$ actin, IFN $\gamma$, TNF $\alpha$, TGF $\beta$, or IL 10) or $3 \mu$ l (IL 2 , IL 4 , IL 5 , or IL 6 ) of the reverse transcription reaction products were amplified in the following PCR solution $(25 \mu \mathrm{l}): 1.8 \mathrm{mM}$ $\mathrm{MgCl}_{2}, 1 \times$ PCR buffer (100 mM TRIS- $\mathrm{HCl}$, $\left.\mathrm{pH} 8 \cdot 3 ; 500 \mathrm{mM} \mathrm{KCl} ; 15 \mathrm{mM} \mathrm{MgCl}_{2}\right), 0.64$ $\mathrm{mM}$ dNTP, $20 \mathrm{pmol}$ of each primer, and 0.6 U Taq DNA Polymerase (Perkin Elmer). PCR was run for 25 cycles ( $\beta$ actin, IFN $\gamma$, TNF $\alpha$, TGF $\beta$, or IL 10 ) or 35 cycles (IL 2 , IL 4 , IL 5, or IL 6) under the following conditions: denaturation $\left(95^{\circ} \mathrm{C}, 30\right.$ seconds), annealing (30 seconds), and extension $\left(75^{\circ} \mathrm{C}, 60 \mathrm{sec}-\right.$ onds). Each reaction mixture $(25 \mu \mathrm{l})$ was electrophoresed at $70 \mathrm{~V}$ for two hours in an $1.5 \%$ (w/v) agarose gel. Table II describes the size of the PCR products, the primer set sequences, and the annealing temperatures for each primer set.

\section{Results}

Expression and secretion of IFN $\gamma$

CELISA was used to measure IFN $\gamma$ in the TCC supernatants. This method was based on induction of HLA-DR in HT-29.E10 cells that is known to be a selective function of IFN $\gamma,{ }^{15}$ although subsequent upregulation of HLA-DR can be synergistically enhanced by TNF $\alpha .^{17}$ Figure 1 shows the results of a representative experiment with supernatants (diluted 1/20) from three DQ2 and five DQ8 restricted TCC after stimulation with gluten in the presence of APC. Dilutions lower than $1 / 20$ caused excessive death of epithelial cells as measured by crystal violet staining. To control for unknown stimulatory factors in this test system, polyclonal antibody to hIFN $\gamma$ was applied in blocking experiments, which verified that the induction of HLA-DR was exclusively caused by this cytokine (Fig 2, upper panel). The overall CELISA results (Table IV) showed that all the 15 TCC secreted considerable amounts of IFN $\gamma$ after gluten stimulation, most of the concentrations being remarkably high $(>2000 \mathrm{U} / \mathrm{ml})$. However, in clone 1.63 induction of IFN $\gamma$ was seen only after addition of exogenous IL 2 to the culture. The control TCC reactive with $M$ tuberculosis (clone 4.97) also produced a high concentration of IFN $\gamma$ (Table IV).

The supernatants (diluted 1/20) from all gluten stimulated TCC also induced expression of secretory component by HT-29.E10 cells, in contrast with culture fluid from unstimulated cells or APC alone (Fig 3 and Table IV). This CELISA result could probably in the main be ascribed to IFN $\gamma$ as supported by blocking experiments with antibody to this cytokine (Fig 2, lower panel), although an additive effect of TNF $\alpha^{17}$ was not excluded (see later).

Slot blot analysis of RNA extracted from two DQ2 restricted TCC (clones 4.32 and $5 \cdot 14)$ showed very little IFN $\gamma$ mRNA in

TABLE IV Cytokine secretion profiles of various intestinal gluten specific TCC compared with TCC reactive with M tuberculosis ${ }^{\star}$

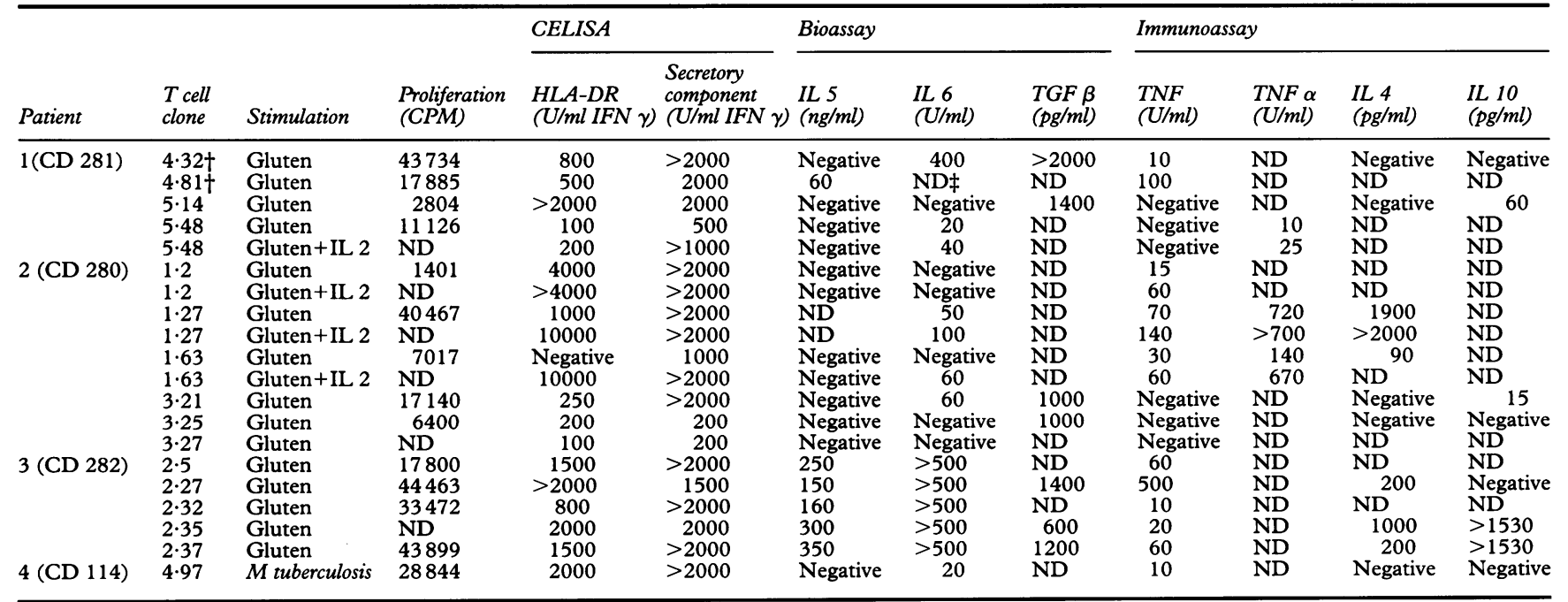

^Fifteen TCC from three patients were investigated, 10 (from patients no 1 and no 2) were DQ2 restricted whereas five (from patient no 3 ) were DQ8 restricted. Cell culture supernatants were prepared and tested after 48 hours stimulation with gluten peptides in the presence of DQ2 $2^{+}$or DQ8 $8^{+}$Epstein-Barr virus transformed B cells used as APC. A TCC reactive with $M$ tuberculosis established from peripheral blood of a coeliac patient (no 4) was included as control. †Sister clones - that is, same $T$ cell receptor genes. $¥ N D$ : not determined. 


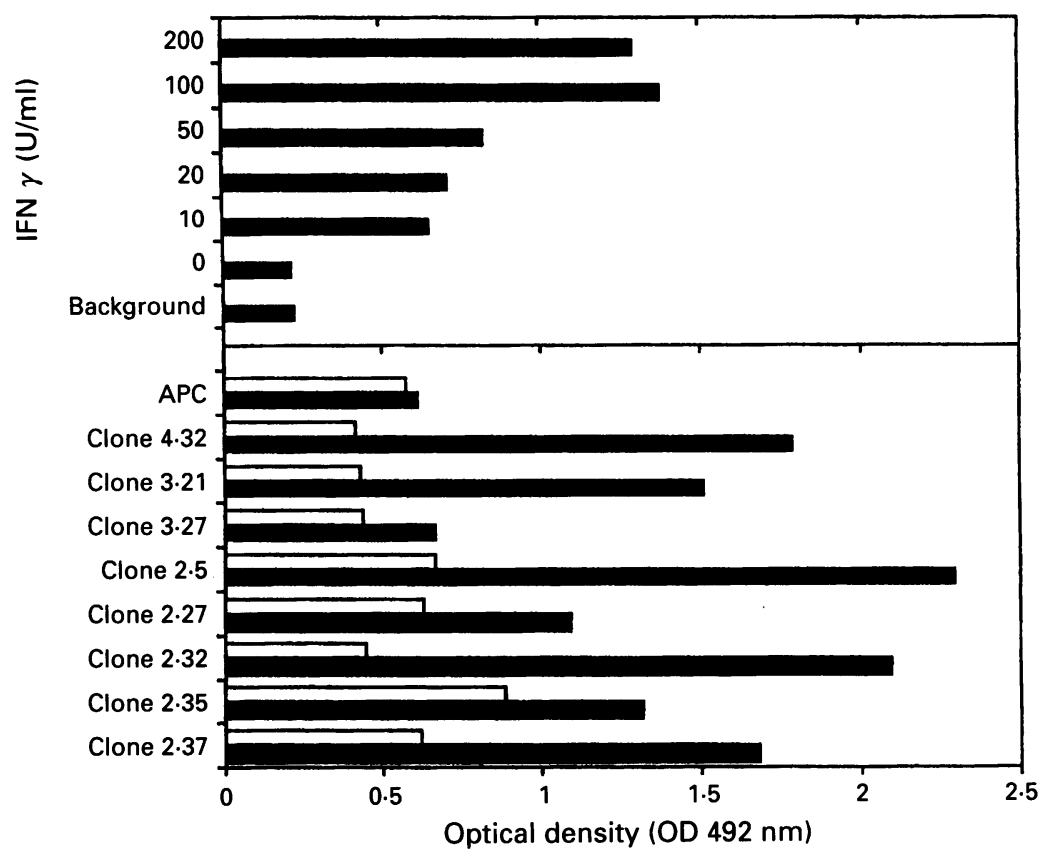

Figure 3: CELISA measurements of secretory component expression by HT-29.E10 cells after stimulation for 48 hours with supernatants (diluted 1/20) from various gluten stimulated T cell clones (D) as shown (lower panel) in relation to APC alone, clonal control without gluten ( $\square$ ), and reference values obtained with 0-200 U/ml of rhIFN $\gamma$ ( $\mathrm{Q}$ ) (upper panel). Results presented as mean OD at $492 \mathrm{~nm}$ of triplicates tested in the same experiment (repeated in a reproducible manner at least twice).
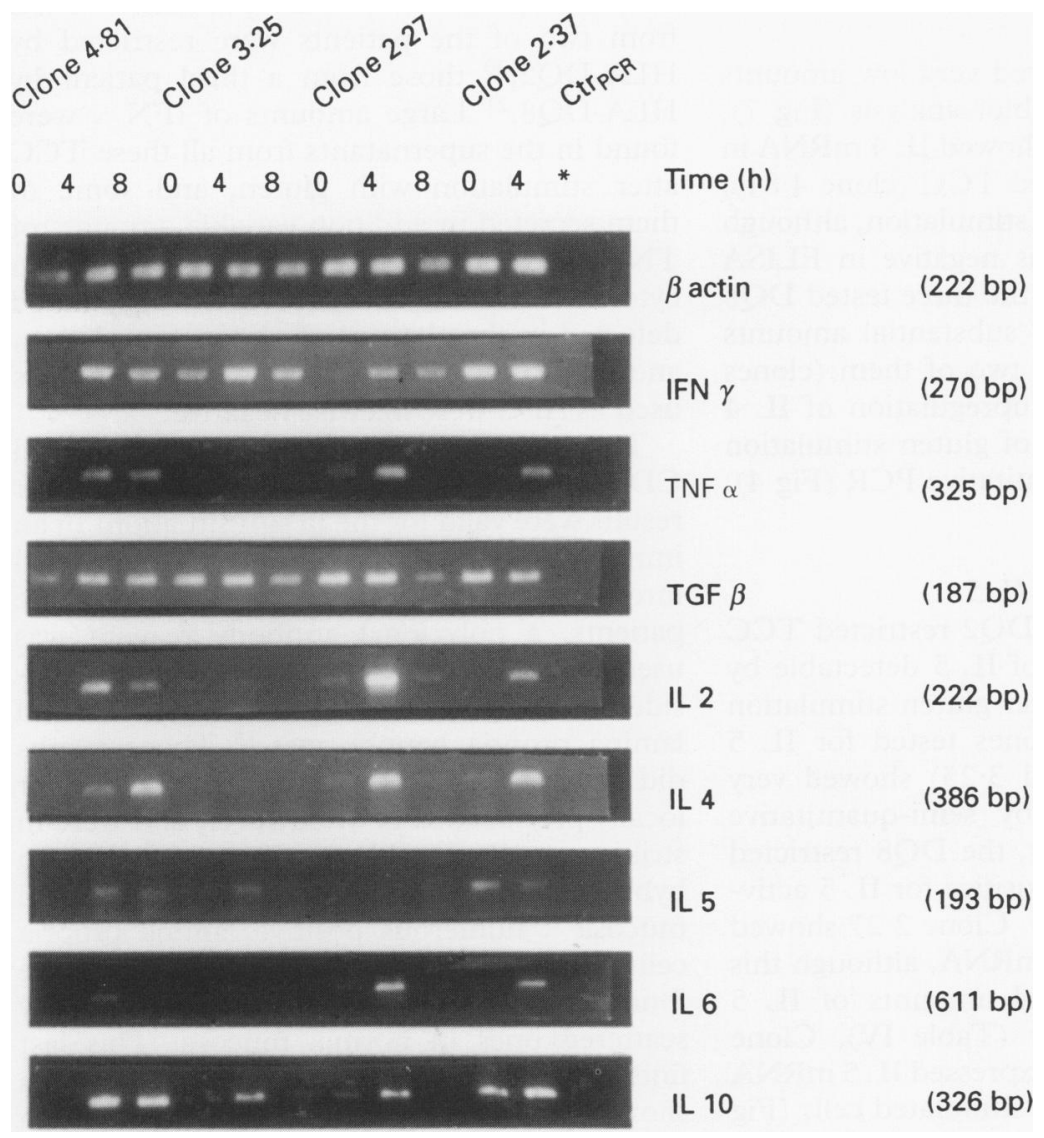

Figure 4: Agarose electrophoresis showing semi-quantitative determination of PCR amplified cytokine $m R N A$ in four $T$ cell clones four hours or eight hours after stimulation, in relation to unstimulated controls $(0)$ as well as a sample containing water $\left(\operatorname{Ctr}_{\mathrm{PCR}^{\star}}{ }^{\star}\right)$. Total RNA (100 ng) was reverse-transcribed to cDNA. Amplification was performed by Total RNA (100 ng) was reverse-transcribed to 25 cycles, or with $3 \mu \mathrm{l}$ cDNA (IL 2, IL 4, IL 5, or IL 6) for 35 cycles. The size of the amplification product as indicated (bp), matched what was predicted from the position of the primer pairs. unstimulated cells (time 0 ) but showed striking upregulation of message after exposure to gluten peptides in the presence of APC for two to four hours for clone 4.32 , decreasing thereafter (Fig 1). Considerably less IFN $\gamma$ mRNA was detected for clone $5 \cdot 14$, whereas this TCC secreted substantial amounts of IFN $\gamma$ tested with CELISA (Table IV). Semi-quantitative PCR performed on four TCC (clones $4 \cdot 81$, $3 \cdot 25,2 \cdot 27$, and $2 \cdot 37$ ) showed IFN $\gamma$ mRNA in all of them after gluten stimulation for four to eight hours; two TCC showed message in unstimulated cells as well (Fig 4). Minor discrepancies between the different methods used might be explained by variations between different cultures of the same TCC and by the high sensitivity of the PCR method.

Expression and secretion of TNF

Ten of the stimulated TCC secreted TNF in the range of $10-500 \mathrm{U} / \mathrm{ml}$ (Table IV), as measured with bioassay (TNF $\alpha$ and TNF $\beta$ ) or ELISA (TNF $\alpha$ ), or both. Although the two assays seemed to produce parallel results, the actual values $(\mathrm{U} / \mathrm{ml})$ obtained were rather discrepant, also the two sister clones 4.32 and 4.81 secreted different amounts of TNF. Figure 5 shows data obtained by bioassay for supernatants from four DQ2 restricted and five DQ8 restricted TCC after stimulation with gluten in the presence of APC. Slot blot analysis of two clones with little or no secretion showed also no convincing upregulation of TNF $\alpha$ mRNA (Fig 5). After semi-quantitative PCR, three of four tested TCC showed TNF $\alpha$ mRNA after four hours of gluten stimulation, whereas one was negative; this was in agreement with the results obtained by bioassay (Fig 4, Table IV).

Expression and secretion of TGF $\beta$

Supernatants from seven TCC contained TGF $\beta$ in the range of $500-2000 \mathrm{pg} / \mathrm{ml}$ as measured by bioassay (diluted $1 / 2$ ), both with and without gluten stimulation, and in APC as well (Fig 6). Semi-quantitative PCR on four TCC showed TGF $\beta$ mRNA in stimulated as well as unstimulated cells (Fig 4).

\section{Expression and secretion of IL 2}

Neither bioassay nor ELISA showed IL 2 in undiluted supernatants of stimulated TCC after 48 hours, whereas traces were detected in a few samples after six hours (clones 4.32, $3 \cdot 25$, and 4.97; data not shown). Semi-quantitative PCR performed on four TCC showed IL 2 mRNA in three of them after gluten stimulation for four hours, while unstimulated cells were negative (Fig 4 ).

Expression and secretion of IL 4

After gluten stimulation only two of six tested DQ2 restricted TCC (clones 1.27 and 1.63) secreted IL 4 as detected by ELISA in undiluted supernatants, whereas the other four were negative (Fig 7, Table IV). Two of the 


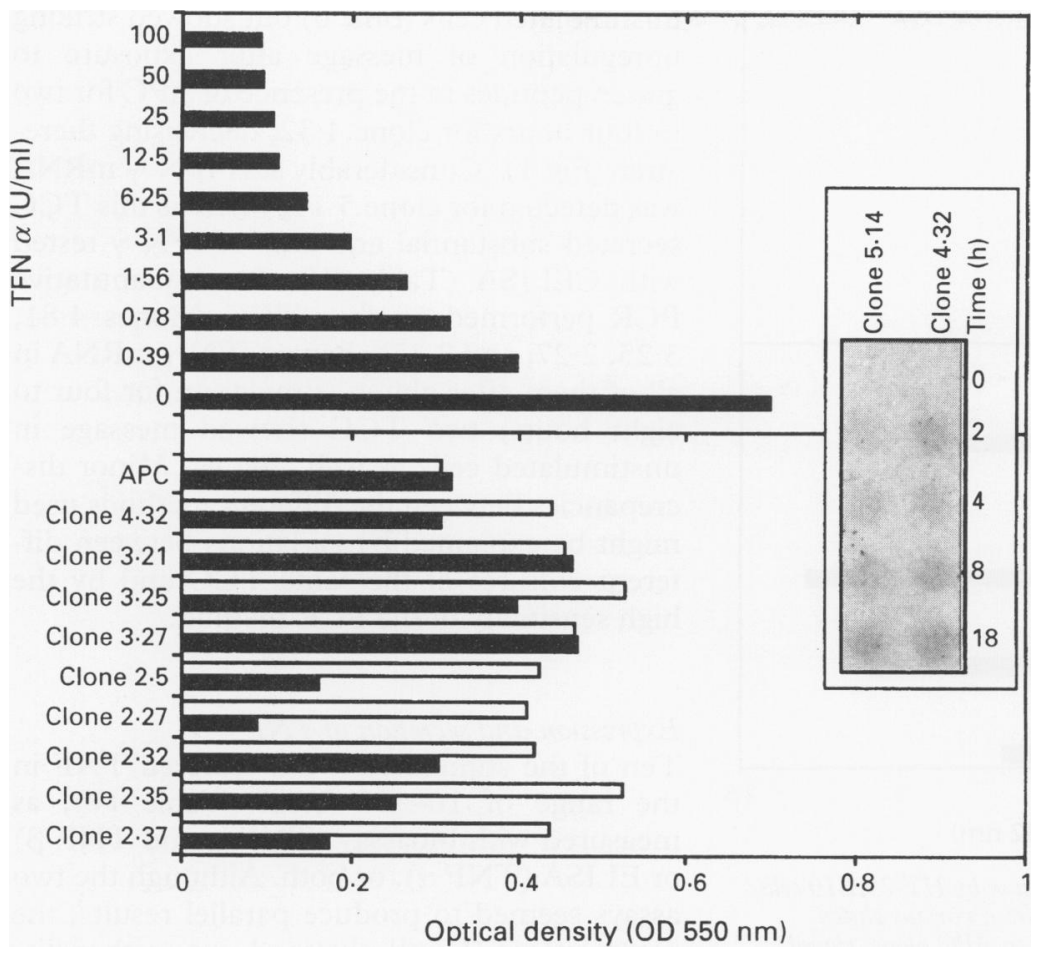

Figure 5: Cytotoxic bioassay of TNF activity in supernatants (diluted 1/10) from various gluten stimulated (48 hours) $T$ cell clones ( $\square$ ) as shown (lower panel) in relation to APC alone, clonal control without gluten ( $\square$ ), and reference values obtained with $0-100 \mathrm{U} / \mathrm{ml}$ of rhTNF $\alpha$ (प) (upper panel). Results presented as mean reduction of $O D$ at $550 \mathrm{~nm}$ of triplicates tested in the same experiment (repeated in a reproducible manner at least twice). Insert shows autoradiogram of slot blot hybridisation results with antisense DNA probe for $T N F \alpha m R N A$ from two gluten stimulated (2-18 hours) $T$ cell clones as shown, compared with unstimulated control ( 0 hours).

negative TCC also showed very low amounts of IL 4 mRNA by slot blot analysis (Fig 7). Semi-quantitative PCR showed IL 4 mRNA in one of the DQ2 restricted TCC (clone $4 \cdot 81$ ), after four hours of gluten stimulation, although the sister clone 4.32 was negative in ELISA (Fig 4, Table IV). All of the three tested DQ8 restricted TCC secreted substantial amounts of IL 4 (Table IV), and two of them (clones $2 \cdot 27$ and $2 \cdot 37$ ) showed upregulation of IL 4 mRNA after four hours of gluten stimulation as detected by semi-quantitative PCR (Fig 4).

Expression and secretion of IL 5

Only one of nine tested DQ2 restricted TCC secreted small amounts of IL 5 detectable by bioassay (diluted 1/2) after gluten stimulation (Table IV), and two clones tested for IL 5 mRNA (clones 4.81 and 3.25 ) showed very low levels of message by semi-quantitative PCR (Fig 4). Conversely, the DQ8 restricted TCC were consistently positive for IL 5 activity in bioassay (Table IV). Clone $2 \cdot 27$ showed no upregulation of IL $5 \mathrm{mRNA}$, although this clone secreted substantial amounts of IL 5 when tested by bioassay (Table IV). Clone $2 \cdot 37$, on the other hand, expressed IL 5 mRNA in both unstimulated and stimulated cells (Fig 4).

Expression and secretion of IL 6

Only four of nine tested DQ2 restricted TCC secreted IL 6 detectable by bioassay (diluted 1/5) after gluten stimulation, and the amounts were comparatively small $(20-400 \mathrm{U} / \mathrm{ml})$, especially without addition of rhIL 2 (Fig 8, Table IV). The five DQ8 restricted TCC all secreted substantial amounts $(>500 \mathrm{U} / \mathrm{ml})$ of IL 6 , and two clones (clones $2 \cdot 27$ and $2 \cdot 37$ ) expressed IL 6 mRNA as shown by semiquantitative PCR (Fig 4). Considerably less IL 6 mRNA was detected in clone $4 \cdot 81$, and clone 3.25 was negative in agreement with the result obtained by bioassay (Table IV).

\section{Expression and secretion of IL 10}

After gluten stimulation two of four tested DQ2 restricted TCC secreted small amount of IL 10 as detected in undiluted supernatants by ELISA, whereas the two others were negative. Conversely, two of three tested DQ8 restricted TCC secreted substantial amounts of IL 10 (Fig 9, Table IV). Semi-quantitative PCR performed on four TCC showed IL 10 mRNA in all of them after gluten stimulation for four to eight hours, and in one unstimulated clone as well.

\section{Discussion}

This study describes for the first time cytokine profiles of antigen stimulated mucosal TCC obtained from the human gut. We used as a model system gluten responsive $\mathrm{CD}^{+}{ }^{+} \mathrm{T}$ cells isolated from in vitro gluten challenge jejunal mucosa of treated coeliac patients. ${ }^{12}$ TCC from two of the patients were restricted by HLA-DQ2, ${ }^{20}$ those from a third patient by HLA-DQ8. ${ }^{21}$ Large amounts of IFN $\gamma$ were found in the supernatants from all these TCC after stimulation with gluten, and some of them secreted in addition variable amounts of TNF, TGF $\beta$, IL 4, IL 5, IL 6, and IL 10. No cytokine secretion, except for TGF $\beta$, could be detected in the absence of gluten stimulation, and the Epstein-Barr virus transformed B cells used as APC were likewise negative.

The major cytokine of activated intestinal $\mathrm{CD}^{+}{ }^{+} \mathrm{T}$ cells thus seems to be IFN $\gamma$ if our results were valid for the in situ situation. In an immunohistochemical study of formalin fixed intestinal biopsy specimens of coeliac disease patients, a polyclonal antibody reagent was used to show the presence of IFN $\gamma$ in a considerable proportion of both intraepithelial and lamina propria lymphocytes. ${ }^{33}$ Those results did not distinguish between receptor bound or locally produced IFN $\gamma$, however, and were in striking contrast with a subsequent in situ hybridisation study of IFN $\gamma$ mRNA in jejunal mucosa ${ }^{34}$; numerous positive lamina propria cells (but no intraepithelial lymphocytes) were found in active coeliac disease but only a few scattered ones in normal mucosa. This last finding was in agreement with our results showing IFN $\gamma$ production by mucosal gluten specific TCC only after stimulation. Also, it accorded well with a report on abundant secretion (plaque assay) of IFN $\gamma$ by lamina propria cells dispersed from Crohn's disease lesions but hardly by counterparts from normal intestinal mucosa. ${ }^{35}$

Heterogeneity among $\mathrm{CD} 4^{+} \mathrm{T}$ cells in terms 


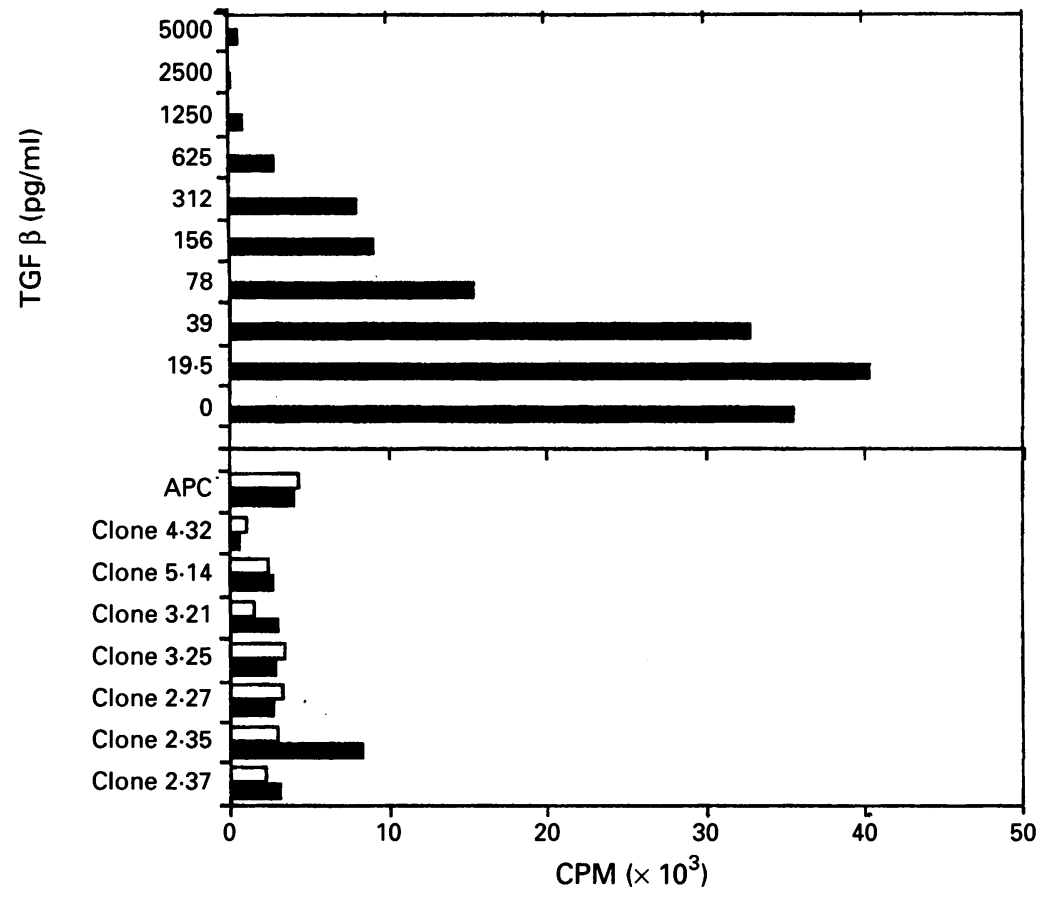

Figure 6: Cytotoxic bioassay of TGF $\beta$ activity in supernatants (diluted 1/2) from various gluten stimulated (48 hours) $T$ cell clones ( $\square$ ) as shown (lower panel) in relation to APC alone, clonal control without gluten ( $\square$ ), and reference values obtained with $0-5000$ $\mathrm{pg} / \mathrm{ml}$ of rhTGF $\beta$ () (upper panel). Results presented as mean ${ }^{3} \mathrm{H}$-thymidine incorporation (CPM) in triplicates tested in the same experiment (repeated in a reproducible manner at least twice).

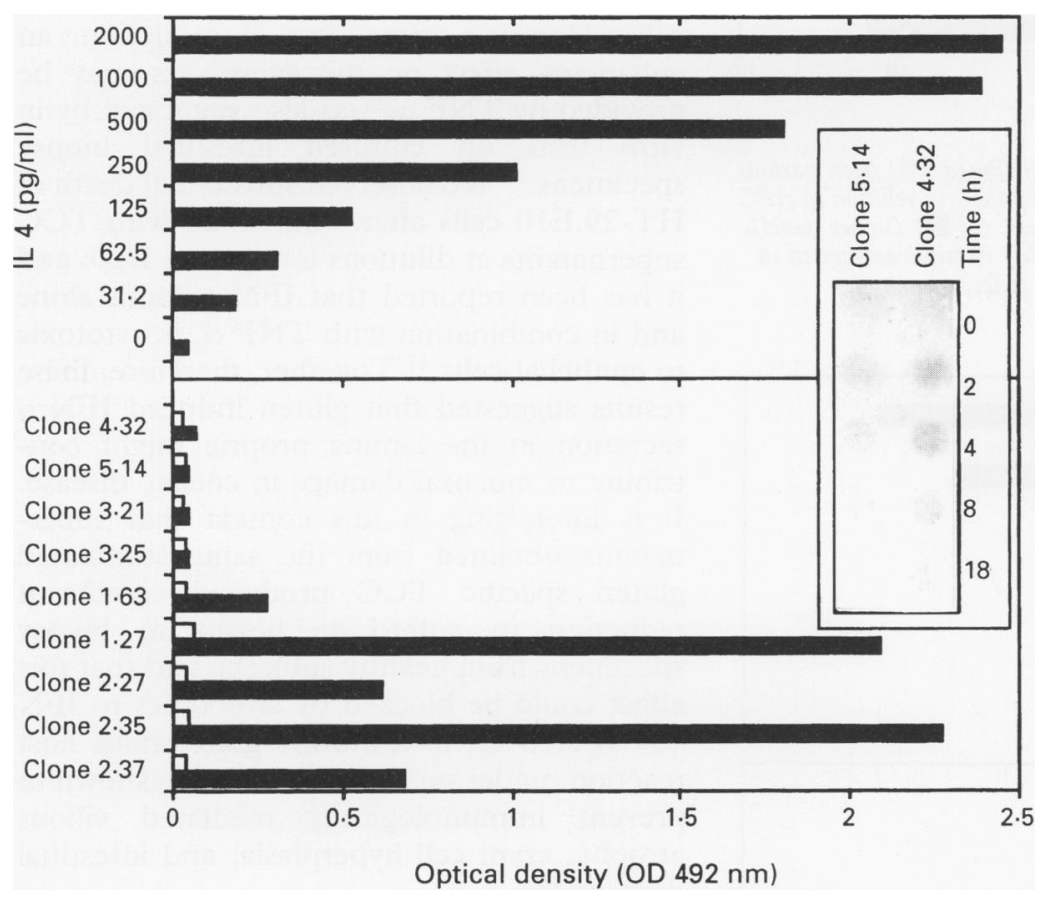

Figure 7: ELISA measurements of IL 4 in supernatants (undiluted) from various gluten stimulated (48 hours) $T$ cell clones ( $)$ as shown (lower panel) in relation to clonal control without gluten ( $\square$ ), and reference values obtained with 0-2000 pg/ml of rhIL 4 (1) (upper panel). Results are presented as mean OD at $492 \mathrm{~nm}$ of duplicates tested in the same experiment. Insert shows autoradiogram after slot blot hybridisation with antisense DNA probe for IL $4 \mathrm{mRNA}$ from two gluten stimulated (2-18 hours) $T$ cell clones as shown, compared with unstimulated control (0 hours).

of cytokine secretion (and thereby functional properties) is well reported in the mouse. ${ }^{36} 37$ Thus, most murine $\mathrm{CD}^{+}$TCC can be categorised in two subsets: Th1 cells that secrete mainly IFN $\gamma$ and IL 2 mediate delayed type hypersensitivity, whereas Th2 cells that secrete mainly IL 4 and IL 5 provide superior help for humoral immunity. ${ }^{38}$ There is some support for the notion that Th1 and Th2 cells are the progeny of Th0 cells, which can produce various cytokines. ${ }^{38}$ Comparable $\mathrm{T}$ cell subsets have recently been defined in humans, although the expression of other cytokines such as IL 2, IL 6, IL 10, and IL 13 may be less restricted than in mice. ${ }^{39}$ The stimulatory antigen clearly plays a major part in determining the cytokine pattern of reactive $T$ cells. Thus, human TCC obtained from peripheral blood of an atopic patient show a Th1-like profile in response to mycobacteria but a Th2-like profile in response to allergens. ${ }^{39}$ The TCC with reactivity against $M$ tuberculosis included as a control in our study fit into this pattern (Table IV).

In view of the prominent production of IFN $\gamma$ as a marker for Th1, and IL 4 together with IL 5 as a marker for Th2, our results suggested that the most frequent cytokine pattern among the gluten specific mucosal TCC was a Th0like profile. Some of the TCC showed a distinct Th1 profile, however, with prominent IFN $\gamma$ but no IL 4 or IL 5 production. It has been claimed that especially IFN $\gamma$ and IL 4 might be critical growth factors in the differentiation of T cell subsets, IFN $\gamma$ augmenting the development of Th1 cells and IL 4 promoting Th2 cells. ${ }^{39}$ The TCC used in our study were propagated with PHA and IL 2; it could not be excluded that this expansion procedure influenced the cytokine profiles obtained. However, several studies based on the same cloning procedure have reported the generation of both Th1 and Th2 human TCC. ${ }^{4041}$

The absence of IL 2 from the supernatants of our TCC after 48 hours stimulation was somewhat surprising. Low values were often found after six hours, however, and PCR showed IL 2 mRNA in three of four TCC tested after four to eight hours of gluten stimulation. The TCC showed strong proliferative response to gluten and incorporated ${ }^{3} \mathrm{H}$-thymidine (Table IV). One possible explanation for the lack of IL 2 in the supernatants could therefore be consumption of this autocrine growth factor by the TCC. Alternatively, the rhIL 2 added during propagation of the TCC might have downregulated their own production of this cytokine, or the sensitivity of the bioassay could be insufficient. Interestingly, oral immunisation with enterotoxigenic Escherichia coli vaccine also induced $\mathrm{T}$ cells (presumably gut derived) with prominent IFN $\gamma$ but no detectable IL 2 secretion. ${ }^{42}$

Differences in the cytokine profiles were seen in the two sister clones 4.32 and 4.81 , although they carried the same $\mathrm{TcR} \alpha / \beta$ genes; such discrepancies might be explained by small variations in growth conditions and also by the fact that our TCC were stimulated in a physiological manner, resulting in some unpredictable variability. Similarly, in a study performed on TCC derived from a $T c R \alpha / \beta$ transgenic mouse there was significant heterogeneity of cytokine expression within each of the cloned Th1, Th2, and Th0 populations. ${ }^{43}$

Coeliac disease shows a strong HLA class II association, predominantly with a $\mathrm{DQ}\left(\alpha 1^{\star} 0501, \beta 1^{\star} 0201\right)$ heterodimer. ${ }^{34}$ 


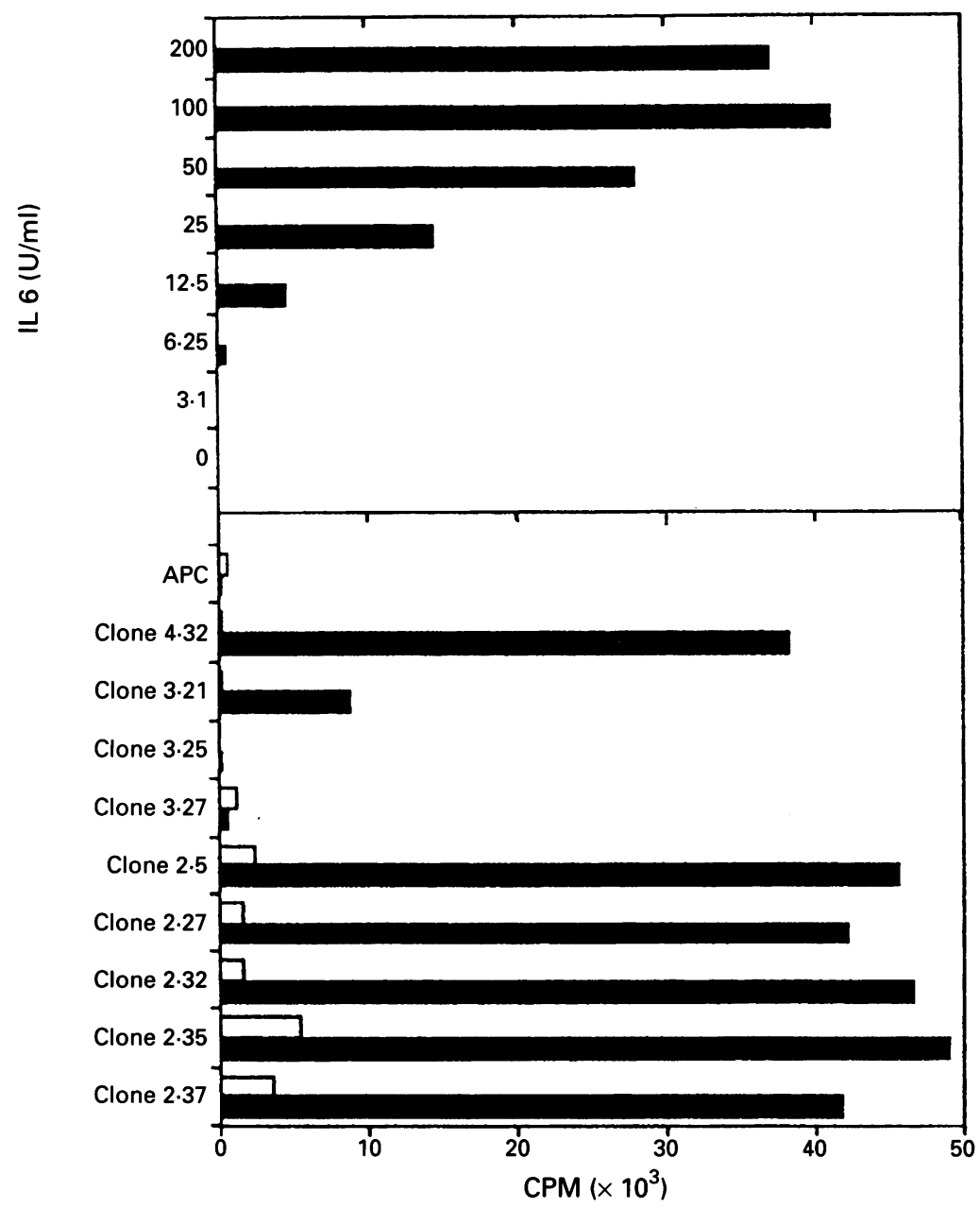

Figure 8: Proliferative bioassay of IL 6 activity in supernatants (diluted 1/5) from various gluten stimulated (48 hours) $T$ cell clones ( $)$ as shown (lower panel) in relation to APC alone, clonal control without gluten ( $\square$ ), and 0-200 U/ml of rhIL 6 ( $\square$ ) (upper panel). Results are presented as mean ${ }^{3} \mathrm{H}$-thymidine incorporation (CPM) in triplicates tested in the same experiment (repeated in a reproducible manner at least twice).

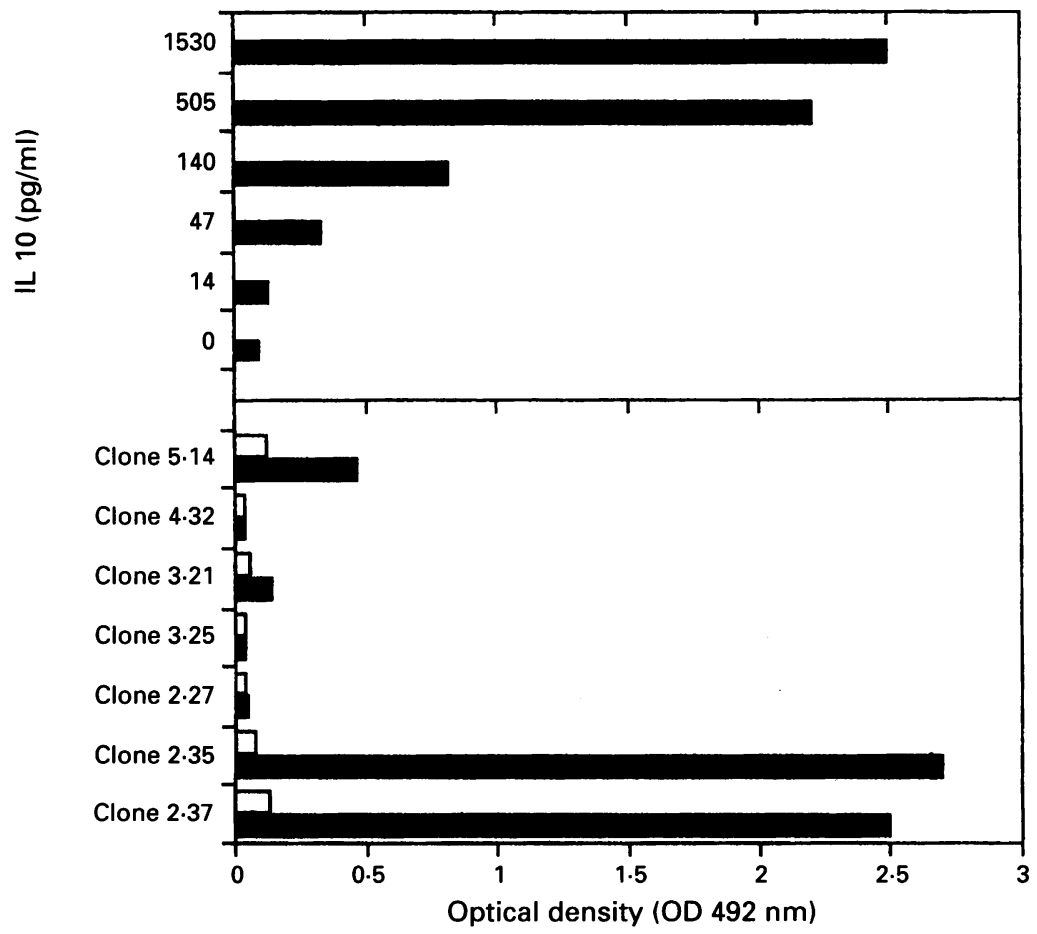

Figure 9: ELISA measurement of IL 10 in supernatants (undiluted) from various gluten stimulated (48 hours) $T$ cell clones ( $)$ as shown (lower panel) in relation to clonal control without gluten ( $\square$ ), and reference values obtained with $0-1530 \mathrm{pg} / \mathrm{ml}$ of rhIL 10 () (upper panel). Results are presented as mean OD at $492 \mathrm{~nm}$ of duplicates tested in the same experiment.
There is accumulating evidence that activated $\mathrm{CD}^{+} \mathrm{T}$ cells in jejunal mucosa play an important immunopathological part in the development of the coeliac lesion. 111244 Because DQ molecules are abundantly expressed by subepithelial APC and hardly by the gut epithelium, ${ }^{12} 45$ gluten peptides are most probably primarily presented to $T$ cells within the lamina propria, although some DR mediated antigen presentation might occur in the epithelium. It is noteworthy in this context that when jejunal mucosal specimens from treated coeliac patients are challenged with gluten in vitro, lamina propria $\mathrm{CD}^{+} \mathrm{T}$ cells but not intraepithelial lymphocytes express the activation marker CD25. ${ }^{12}$ The gluten reactive TCC used in this study are therefore most probably derived from ex vivo stimulated lamina propria $\mathrm{T}$ cells. ${ }^{20-22}$

Significantly increased expression of HLADR was seen on HT-29.E10 cells after exposure to supernatants from gluten stimulated TCC. This agreed with the fact that the active coeliac lesion shows increased epithelial expression of class II molecules in a differential fashion - that is, DR $>\mathrm{DP}>\mathrm{DQ},{ }^{45}$ and rhIFN $\gamma$ can differentially induce these molecules on HT-29.E10 cells. ${ }^{15}$ Thus, the aberrant epithelial class II expression seen in the coeliac lesion is most probably explained mainly by the release of IFN $\gamma$ from activated mucosal T cells. However, after class II induction, an enhancing effect on the expression may be provided by TNF $\alpha,{ }^{17}$ as also suggested by in vitro tests on cultured intestinal biopsy specimens. ${ }^{46} \mathrm{We}$ observed substantial death of HT-29.E10 cells after stimulation with TCC supernatants at dilutions lower than $1 / 20$; and it has been reported that IFN $\gamma$, both alone and in combination with TNF $\alpha$, is cytotoxic to epithelial cells. ${ }^{47}$ Together, therefore, these results suggested that gluten induced IFN $\gamma$ secretion in the lamina propria might contribute to mucosal damage in coeliac disease. It is interesting in this context that supernatants obtained from the same stimulated gluten specific TCC produced significant reduction in enterocyte height in biopsy specimens from healthy subjects, and that this effect could be blocked by antibodies to IFN $\gamma .{ }^{48}$ Moreover, in a murine graft versus host reaction model such antibodies were shown to prevent immunologically mediated villous atrophy, crypt cell hyperplasia, and intestinal damage. ${ }^{49}$

The active coeliac lesion also shows increased epithelial expression of secretory component, ${ }^{50}$ and IFN $\gamma$, TNF $\alpha$ as well as IL 4 can upregulate this polymeric immunoglobulin receptor on HT-29.E10 cells. ${ }^{16-18} 5152$ Buturate, a normal fermentation product in the large bowel, considerably enhances this effect of the two former cytokines. ${ }^{52}$ Interestingly, the supernatants of our gluten stimulated TCC were directly shown to upregulate secretory component. Enhanced expression of the polymeric immunoglobulin receptor in vivo would promote the external transport of dimeric IgA and pentameric IgM antibodies, which indeed is known to be the 
case in coeliac disease; mucosal overproduction of IgM and luminal delivery of secretory IgM antibodies to gluten do in fact seem to be an early marker of disease activation. ${ }^{53}$ Perhaps complement activating IgM antibodies bound to secretory component basolaterally on the jejunal epithelium exert an immunological attack. ${ }^{54}$ Supernatants from our TCC were also found to contain IL 10 and TGF $\beta$ after gluten stimulation, and TGF $\beta$ was secreted by unstimulated cells as well. This last cytokine, particularly in cooperation with IL 10, may enhance IgA secretion by activated human $\mathrm{B}$ cells, probably as a consequence of class switching. ${ }^{55}$

In conclusion, mucosal exposure to gluten in genetically predisposed subjects will induce hyperactivation of $\mathrm{CD}^{+}$lamina propria $\mathrm{T}$ cells, which through their $\mathrm{Th} 1$ and $\mathrm{Th} 0$ cytokine repertoire most probably contribute not only to the intensified and unbalanced local B cell response, ${ }^{53}$ but also to crypt hyperplasia, ${ }^{14} 44$ enhanced epithelial expression of secretory component (polymeric immunoglobulin receptor) and HLA class $\mathrm{II},{ }^{50}$ increased epithelial permeability, ${ }^{13}$ and epithelial damage. ${ }^{14} 4748$ Mucosal T cell activation in an HLA-DQ restricted fashion thus seems to play a central part in the pathogenesis of coeliac disease.

This study was supported by the Norwegian Cancer Society, the Research Council of Norway, and Pronova. E M Nilsen is a Research Fellow of the University of Oslo. We thank Drude Hansson, Guri Jørum, Kari G Lislerud, Tone Narvesen, and Bjørg Simonsen for invaluable technical assistance, and Hege Svendsen for excellent secretarial assistance. Kind donations of various reagents have been acknowledged in the text.

1 Trier JS. Celiac sprue. $N$ Engl f Med 1991; 325: 1709-19. 2 Marsh MN. Gluten, major histocompatibility complex, and the small intestine. Gastroenterology 1992; 102: 330-54.

3 Sollid LM, Markussen G, Ek J, Gjerde H, Vartdal F, Thorsby E. Evidence for a primary association of celiac disease to a particular HLA-DQ a/ $\beta$ heterodimer. $\mathcal{f}$ Exp Med 1989; 169: 345-50.

4 Sollid LM, Thorsby E. HLA susceptibility genes in celiac disease: genetic mapping and role in pathogenesis. Gastroenterology 1993; 105: 910-22.

5 Spurkland A, Sollid LM, Polanco I, Vartdal F, Thorsby E. HLA-DR and -DQ genotypes of celiac disease patients serologically typed to be non-DR3 or non-DR5/7. Hum Immunol 1992; 35: 188-92.

6 Mantovani V, Corazza GR, Bragliani M, Frisoni M, Zaniboni MG, Gasbarrini G. Asp57-negative HLA DQ $\beta$ chain and $\mathrm{DQA} 1{ }^{\star} 0501$ allele are essential for the onset of DQw2-positive and DQw2-negative coeliac disease. Clin Exp Immunol 1993; 91: 153-6.

7 Crabtree JE, Heatley RV, Juby LD, Howdle PD, Losowsky MS. Serum interleukin-2-receptor in coeliac disease: response to treatment and gluten challenge. Clin Exp Immunol 1989; 77: 345-8.

8 Sturgess RP, Macartney JC, Makgoba MW, Hung $\mathrm{CH}$, Haskard DO, Ciclitira PJ. Differential upregulation of Haskard DO, Ciclitira PJ. Differential upregulation of
intercellular adhesion molecule-1 in coeliac disease. Clin intercellular adhesion molecule-1

9 Fais S, Maiuri L, Pallone F, De Vincenzi M, De Ritis G, Troncone $\mathrm{R}$, et al. Gliadin induced changes in the expression of MHC-class II antigens by human small intestinal epithelium. Organ culture studies with coeliac disease mucosa. Gut 1992; 33: 472-5.

10 Scott H, Kett K, Halstensen TS, Hvatum M, Rognum TO, Brandtzaeg P. The humoral immune system in coeliac disease. In: Marsh MN, ed. Coeliac disease. Oxford: Blackwell Scientific, 1992: 239-82.

11 Halstensen TS, Brandtzaeg P. Activated T lymphocytes in the celiac lesion: non-proliferative activation (CD25) of the celiac lesion: non-proliferative activation (CD25) of 67) of $\alpha / \beta$ and $\gamma / \delta$ cells in the epithelium. Eur $\mathcal{F}$ Immunol

12 Halstensen TS, Scott H, Fausa O, Brandtzaeg P. Gluten stimulation of coeliac mucosa in vitro induces activation (CD25) of lamina propria $\mathrm{CD4}^{+} \mathrm{T}$ cells and macrophages but no crypt-cell hyperplasia. Scand $\mathcal{F}$ Immunol 1993; 38: 581-90.

13 Madara JL, Stafford J. Interferon- $\gamma$ directly affects barrier function of cultured intestinal epithelial monolayers. f Clin Invest 1989; 83: 724 .

14 Lionetti P, Breese E, Braegger CP, Murch SH, Taylor J,
MacDonald TT. T-cell activation can induce either mucosal destruction or adaption of cultured human fetal small intestine. Gastroenterology 1993; 105: 373-81.

15 Sollid LM, Gaudernack G, Markussen G, Kvale D, Brandtzaeg $\mathrm{P}$, Thorsby $\mathrm{E}$. Induction of various HLA class II molecules in a human colonic adenocarcinoma cell lines. Scand F Immunol 1987; 25: 175-80.

16 Sollid LM, Kvale D, Brandtzaeg P, Markussen G, Thorsby E. Interferon- $\gamma$ enhances expression of secretory component, the epithelial receptor for polymeric immunonent, the epithelial receptor for polym
globulins. F Immunol 1987; 138: 4303-6.

17 Kvale D, Brandtzaeg P, Lovhaug D. Up-regulation of the expression of secretory component and HLA molecules in a human colonic cell line by tumour necrosis factor- $\alpha$ and gamma interferon. Scand $\mathcal{F}$ Immunol 1988; 28: 351-7.

18 Phillips JO, Everson MP, Moldoveanu Z, Lue C, Mestecky J. Synergistic effect of IL -4 and IFN- $\gamma$ on the expression of polymeric Ig receptor (secretory component) and IgA binding by human epithelial cells. $\mathcal{F}$ Immunol 1990; 145: 1740-4.

19 McGhee JR, Mestecky J, Elson CO, Kiyono H. Regulation of IgA synthesis and immune response by $T$ cells and interleukins. f Clin Immunol 1989; 9: 175-99.

20 Lundin KEA, Scott H, Hansen T, Paulsen G, Halstensen TS, Fausa O, et al. Gliadin-specific, HLA$\mathrm{DQ}\left(\alpha 1^{\star} 0501, \beta 1^{\star} 0201\right)$ restricted $\mathrm{T}$ cells isolated from the small intestinal mucosa of celiac disease patients. $\mathcal{f}$ Exp Med 1993; 178: 187-96.

21 Lundin KEA, Scott H, Fausa O, Thorsby E, Sollid LM. T cells from the small intestinal mucosa of a DR4,DQ7/DR4,DQ8 celiac disease patient preferentially recognize gliadin when presented by DQ8. Hum Immunol 1994; 41: 285-91.

22 Lundin KEA, Gjertsen HA, Scott H, Sollid LM, Thorsby E. Function of DQ2 and DQ8 as HLA susceptibility molecules in celiac disease. Hum Immunol 1994; 41: 24-7.

23 Karasuyama H, Melchers F. Establishment of mouse cell lines which constitutively secrete large quantities of interleukin $2,3,4$ or 5 , using modified cDNA expression vectors. Eur f Immunol 1988; 18: 97-104.

24 Watson J. Continous proliferation of murine antigenspecific helper T lymphocytes in culture. $\mathcal{F}$ Exp Med 1979; 150: 1510-9.

25 Helle M, Boeije L, Aarden LA. Functional discrimination between interleukin 6 and interleukin 1. Eur f Immunol 1988; 18: 1535-40.

26 Fattah D, Quint DJ, Proudfoot A, O'Malley R, Zanders $E D, C h a m p i o n ~ B R$. In vitro and in vivo studies with purified recombinant human interleukin 5. Cytokine 1990; 2: 122-21.

27 Espevik T, Nissen-Meyer J. A highly sensitive cell line, WEHI 164 clone 13, for measuring cytotoxic factor/tumor necrosis factor from human monocytes. I Immunol Methods 1986; 95: 99-105.

28 Mosmann T. Rapid colorimetric assay for cellular growth and survival: application to proliferation and cytotoxicity assays. F Immunol Methods 1983; 65: 55-63.

29 Danielpour D, Dart LL, Flanders KC, Roberts AB, Sporn $M B$. Immunodetection and quantitation of the two forms of transforming growth factor-beta (TGF- $\beta 1$ and TGFB2) secreted by cells in culture. F Cell Physiol 1989; 138: 79-86.

30 Kvale D, Krajči, P, Brandtzaeg P. Expression and regulation of adhesion molecules ICAM-1 (CD54) and LFA-3 (CD58) in human intestinal epithelial cell lines. Scand $\mathcal{f}$ Immunol 1992; 35: 669-76.

31 MacDonald RJ, Swift GH, Przybyla AE, Rutters WJ, Chirgwin JM. Isolation of RNA using guanidium salts. Methods Enzymol 1979; 152: 219-34.

32 Bonner TI, Brenner DJ, Neufeld BR, Britten RJ. Reduction in the rate of DNA reassociation by sequence divergence. f Mol Biol 1973; 81: 123-35.

33 Al-Dawoud A, Nakshabendi I, Foulis A, McI Mowat A. Immunohistochemical analysis of mucosal gammainterferon production coeliac disease. Gut 1992; 33: 1482-6.

34 Kontakou M, Sturgess RP, Przemioslo RT, Limb GA, Nelufer JM, Ciclitira PJ. Detection of interferon-gamma Nelufer JM, Ciclitira PJ. Detection of interferon-gamma mRNA in the mucosa of patients with coeliac

35 Breese E, Braegger CP, Corrigan CJ, Walker-Smith JA, MacDonald TT. Interleukin-2- and interferon - secreting $\mathrm{T}$ cells in normal and diseased human intestinal mucosa. Immunology 1993; 78: 127-31.

36 Mosmann TR, Cherwinski H, Bond MW, Giedlin MA, Coffman RL. Two types of murine $T$ cell clone. Definition according to profiles of lymphokine activities and secreted proteins. ff Immunol 1986; 136: 2348-57.

37 Swain SL, Bradley LM, Croft M, Tonkonogy S, Atkins G, Weinberg AD, et al. Helper T-cell subsets: phenotype, function and the role of lymphokines in regulating their development. Immunol Rev 1991; 123: 115-44.

38 Mosmann TR, Coffman RL. TH1 and TH2 cells: different patterns of lymphokine secretion lead to different funcpatterns of lymphokine secretion lead to different func-

39 Romagnani S. Human TH1 and TH2 subsets: regulation of differentiation and role in protection and immunopathology. Int Arch Allergy Immunol 1992; 98: 279-85.

40 Parronchi P, Macchia D, Piccinni MP, Biswas P, Simonelli $\mathrm{C}$, Maggi E, et al. Allergen- and bacterial antigen-specific $\mathrm{T}$-cell clones established from atopic donors show a different profile of cytokine production. Proc Natl Acad Sci 1991; 88: 4538-42.

41 Del Prete GF, De Carli M, Ricci M, Romagnani S. Helper activity for immunoglobulin synthesis of T helper type 1 
(Th1) and Th2 human $T$ cell clones: the help of Th1 clones is limited by their cytolytic capacity. $\mathcal{f}$ Exp Med 1991; 174: 809-13.

42 Wennerås C, Svennerholm AM, Czerkinsky C. Vaccinespecific $T$ cells in human peripheral blood after oral immunization with an inactivated enterotoxigenic Escherichia coli vaccine. Infect Immun 1994; 62: 874-9.

43 Bucy RP, Panoskaltsis-Mortari A, Huang G, Li J, Karr L, Ross $\mathrm{M}$, et al. Heterogeneity of single cell cytokine gene expression in clonal T cell populations. $\mathcal{F}$ Exp Med 1994; 180: $1251-62$.

44 MacDonald TT, Spencer J. Evidence that activated mucosal $T$ cells play a role in the pathogenesis of enteropathy in human small intestine. $\mathcal{f}$ Exp Med 1988; 167: 1341-9.

45 Scott H, Sollid LM, Fausa O, Brandtzaeg P, Thorsby E. Expression of major histocompatibility complex class II subregion products by jejunal epithelium in patients with coeliac disease. Scand $f$ Immunol 1987; 26: 563-71.

46 Sturgess RP, Hooper LB, Spencer J, Hung CH, Nelufer JM, Ciclitira PJ. Effects of interferon- $\gamma$ and tumour necroJM, Ciclitira PJ. Effects of interferon- $\gamma$ and tumour necro-
sis factor- $\alpha$ on epithelial HLA class-II expression in sis factor- $\alpha$ on epithelial HLA class-II expression in
jejunal mucosal biopsy specimens cultures in vitro. Scand jejunal mucosal biopsy specimens

47 Deem RL, Shanahan F, Targan SR. Triggered human mucosal $T$ cells release tumour necrosis factor-alpha and interferon-gamma which kill human colonic epithelial cells. Clin Exp Immunol 1991; 83: 79-84.

48 Przemioslo RT, Lundin KEA, Sollid LM, Nelufer J, Ciclitira PJ. Histological changes in small bowel mucosa induced by gliadin sensitive T-lymphocytes can be blocked by anti-interferon- $\gamma$ antibody. Gut 1995; 36: 857-63.

49 Mowat A McI. Antibodies to IFN- $\gamma$ prevent immunologically mediated intestinal damage in murine graftversus-host reaction. Immunology 1989; 68: 18-23.

50 Scott H, Brandtzaeg P, Solheim BG, Thorsby E. Relation between HLA-DR-like antigens and secretory component (SC) in jejunal epithelium of patients with coeliac disease (SC) in jejunal epithelium of patients with coeliac disease or dermati 8 .

51 Krajči, $P$, Taskèn $K$, Kvale $D$, Brandtzaeg P. Interferon- $\gamma$ stimulation of messenger RNA for human secretory component (poly-Ig receptor) depends on continous intermediate protein synthesis. Scand F Immunol 1993; 37: 251-6.

52 Kvale D, Brandtzaeg P. Constitutive and cytokine-induced expression of HLA molecules, secretory component (SC), and ICAM-1 are modulated by butyrate in the colonic epithelial cell line HT-29. Gut 1995; 36: 737-42.

53 Brandtzaeg P, Halstensen TS, Hvatum M, Kvale D, Scott $H$. The serologic and mucosal immunological basis of celiac disease. In: Vol 11. Walker WA, Harmatz PR, Wershil BK, eds. Immunophysiology of the Gut. BristolMyers Squibb/Mead fohnson Nutrition Symposia. London: Myers Squibb/Mead Fohnson Nutritio

54 Halstensen TS, Hvatum M, Scott H, Fausa O, Brandtzaeg P. Association of subepithelial deposition of activated complement and immunoglobulin $G$ and $M$ response to gluten in celiac disease. Gastroenterology 1992; 102: 751-9.

55 Defrance T, Vanbervleit B, Briere F, Durand I, Rousset F, Banchereau J. Interleukin 10 and transforming growth factor $\beta$ cooperate to induce anti-CD40-activated naive human B cells to secrete immunoglobulin A. 7 Exp Med 1992; 175: 671-82. 